\title{
(A)creditação de testemunhas: práticas judiciais na Instrução e Julgamento de crimes de drogas no Brasil e na Espanha
}

\author{
(A)crediting witnesses: judicial practices in the Instruction and \\ Trial of drug crimes in Brazil and Spain
}

Marilha Gabriela Reverendo Garau ${ }^{1}$

\begin{abstract}
RESUMO
O presente trabalho tem por objetivo descrever e analisar, de forma contrastiva, discursos, práticas, e moralidades presentes nas representações de juízes criminais ao valorar provas testemunhais em casos de tráfico de drogas. Partindo da descrição densa de Audiências Criminais na Baixada Fluminense do Rio de Janeiro e de Juzgados de Instrucción e Juicios Orales na capital de Málaga, identifico que no contexto local o processo de equação de versões apresentadas perpassa pela identificação desigual daqueles que se apresentam em juízo. A característica da inquisitorialidade, expressa na presunção de veracidade de documentos produzidos pelas instituições, reforça a presunção da culpabilidade do réu, bem como de inverdade de versões erigidas pela defesa. No contexto estrangeiro da outra sensibilidade jurídica da tradição da Civil Law, embora também exista um perfil de sujeição criminal delimitado, as versões apresentadas por réus e demais testemunhas são levadas ao centro do processo. Ainda que a verdade seja construída, a partir de lógicas adversariais, em Málaga não opera um processo de exclusão discursiva de determinados sujeitos a partir da classificação de (a)creditáveis.
\end{abstract}

\section{PALAVRAS-CHAVE:}

Sensibilidades jurídicas; tráfico de drogas; tradição inquisitorial; testemunhas.

\begin{abstract}
The present work aims to describe and analyze, in a contrasting way, speeches, practices, and moralities present in the representations of criminal judges when valuing testimonial evidence in drug trafficking cases. Starting from the dense description of Criminal Hearings in the Baixada Fluminense of Rio de Janeiro and Juzgados de Instrucción and Juicios Orales in the capital of Malaga, I identify that in the local context the process of equation of versions presented goes through the unequal identification of those who present themselves in court. The characteristic of inquisitoriality, expressed in the presumption of veracity of documents produced by the institutions, reinforces the presumption of the defendant's guilt, as well as the untruth of versions erected by the defense. In the foreign context of the other legal sensitivity of the Civil Law tradition, although there is also a delimited profile of criminal subjection, the

\footnotetext{
${ }^{1}$ Doutora em Ciências Jurídicas e Sociais (PPGSD/UFF). Pesquisadora associada ao Instituto de Estudos Comparados em Administração Institucional de Conflitos (INCT-inEAC) e ao Laboratório de Estudos sobre Conflito, Cidadania e Segurança Pública (Laesp).
} 
versions presented by defendants and other witnesses are brought to the center of the process. Although the truth is constructed from adversarial references, in Malaga there is no process of discursive exclusion of certain subjects classified as (a)credible.

\section{KEYWORDS:}

Legal sensitivities; drug trafficking; inquisitorial tradition; witnesses.

\section{INTRODUÇÃOO}

O presente trabalho é parte da minha tese de doutorado, uma etnografia resultante da pesquisa comparada por contraste sobre o processamento e julgamento de crimes envolvendo casos classificados como tráfico de drogas no Brasil e na Espanha. Especificamente neste artigo pretendo refletir sobre o ritual judiciário a partir da apresentação de audiências sobre fatos classificados como crime no contexto de Málaga e na Baixada Fluminense.

No Brasil e na Espanha a legislação deixou em aberto os critérios objetivos para distinção entre usuários e traficantes, porém no caso do segundo país uma decisão jurisprudencial direcionada por um estudo elaborado pelo Instituto Nacional de Toxicologia, com base em estudos científicos, em outubro de 2001 teria transformado a forma como a questão é tratada no contexto local. Tal estudo fixou uma tabela com as doses mínimas de consumo diário e consumo máximo semanal, além de quantidades significativas, para direcionar a aplicação de agravantes em casos específicos com notória quantidade de drogas. A Lei 11.343/2006 redirecionou o tratamento jurídico-penal das figuras de usuários e traficantes. Enquanto os casos tipificados como uso estão isentos de qualquer pena privativa de liberdade, o traficante pode ser punido com penas bases que variam da mínima de 5 (cinco) a máxima de 15 (quinze).

A caracterização de um indivíduo enquanto usuário ou traficante ocorre geralmente a partir de um flagrante que é presenciado pela figura de dois ou mais policiais militares. Luciana Boiteux (2008) enfatiza esses flagrantes, geralmente envolvem pessoas portando pouca quantidade de droga e nenhum armamento. Os réus não têm antecedentes. $\mathrm{O}$ argumento foi 
confirmado pelo recente estudo de Marcelo Semer (2019) ao concluir que os réus dos processos sobre tráfico de drogas são em regra pobres e primários, cujas apreensões de drogas são feitas em quantidade modesta, sempre presos sem maiores investigações, em geral por flagrante delito em ações da PM. Assim, o trabalho busca colocar em contraste discursos e práticas institucionais de sensibilidades jurídicas locais específicas, pensando o cenário brasileiro a partir da mobilização das práticas e discursos observados no contexto espanhol.

Nesta esteira busco colocar sob descrição as práticas judiciárias de duas sensibilidades jurídicas que compartilham características cruciais para a construção de um problema de pesquisa comparada. A experiência de vivenciar ambientes e espaços distantes da própria sociedade na qual se está inserido, vivenciando-se o convívio em outra sociedade na qual os indivíduos compartilham outros valores e outras formas de sociabilidade ajudam a compreender muito mais sobre a própria sociedade (EILBAUM, 2012, p. 2003). Guiada por uma perspectiva comparada, no sentido de realizar uma comparação não por semelhança, mas contrastando as diferenças (LIMA, 2008), após dois anos de interlocução com atores do judiciário carioca, imergi no contexto Málaga, onde morei de outubro de 2018 até agosto de 2019.

O ritual do Juicio Oral e do Juicio Rápido são apresentados a partir de um referencial comparado por contraste com o objetivo de apresentar e identificar as principais características do ritual das Audiências de Instrução de Julgamento. Tal descrição possibilita compreender de que forma duas sensibilidades jurídicas pertencentes à tradição da Civil Law atribuem significados locais à noção de presunção de inocência, produção de provas e construção de verdade. Em Málaga o Juicio Oral coloca a versão do réu no centro do processo e inaugura uma nova fase que permite a produção de provas por parte da defesa, enquanto no Rio de Janeiro as audiências são conduzidas como parte da prerrogativa estatal, no sentido de resguardar a presunção de culpa do réu, viabilizando a condenação e, portanto, como mera formalidade. A dinâmica concede crédito aos réus e às respectivas provas e versões produzidas pela defesa. No contexto específico do campo na Baixada Fluminense chamo a atenção para a análise das Audiências de Instrução e Julgamento a partir da discussão que coloca sob foco de descrição dois casos concretos, no intuito de explicitar que as exclusões discursivas no âmbito do procedimento são orientadas por uma noção que concede (des)crédito de forma desigual à sujeitos identificados enquanto precários. 


\section{PLANTÕes do SERVICIO DE GUARDia: CRIMES DE DROGAS E A CONSTRUÇÃO DO SUJEITO CRIMINAL EM MÁLAGA}

Ao longo de minha pesquisa acompanhei cinco plantões do Servicio de Guardia em Málaga. O plantão é uma das principais atribuições do juiz da instrução. Em Málaga o Juzgado de Instrucción em serviço de guarda funciona 24 horas por dia todos os dias da semana e, nos períodos de recesso forense, bem como dos demais feriados nacionais, de segunda a sexta feira de nove da manhã às sete da noite. A maior parte do trabalho do juiz nesse período envolve casos em flagrante. As notatio criminis enviadas tratam de pedidos de medidas cautelares e de prisão preventiva. Outro pedido bastante recorrente está relacionado à proteção de vítimas de violência doméstica.

A notificação oral sobre flagrantes delitos chega ao juiz da instrução antes do documento “notatio criminis", através de um telefonema da polícia. Há nesse contexto uma preocupação de que o indivíduo não permaneça detido sem determinação judicial por mais de 72 horas sem a avaliação de um juiz, o que, pela legislação espanhola, torna a prisão ilegal. Embora a comunicação formal, geralmente, seja feita de forma escrita, na prática de determinados fatos delituosos, a comunicação de ocorrências e flagrante acontece por telefone.

Numa dessas ocasiões acompanhei o plantão de uma juíza da instrução. Quando o telefone tocou anunciando sobre a apreensão de um homem marroquino portando 30 gramas de haxixe numa zona de praia da cidade, além de determinar a prisão preventiva do homem, a juíza também decidiu pela abertura de um procedimento investigatório com objetivo de apurar a ligação dele com cartéis do tráfico internacional na Espanha e no Marrocos. Ela autorizou a quebra do sigilo telefônico e avaliação das mensagens do celular que ele trazia consigo. A juíza também encaminhou o caso ao Juzgado de Instrucción Administrativa para que a situação de regularidade da imigração do homem fosse objeto de apuração em um processo na esfera administrativa.

A questão do imigrante no sistema de justiça criminal (e fora dele) apareceu em muitas situações do trabalho de campo. Nos discursos de muitos dos meus interlocutores os imigrantes são associados aos números de criminalidade e violência no país. Mesmo entre meus colegas de turma acadêmicos e advogados, esta ideia era fortemente difundida. A imagética de 
violência, pobreza e criminalidade apareceu em seus discursos atrelada à imagem do estrangeiro-imigrante. Identifiquei assim que nas representações sociais sobre a figura do imigrante, algo que muito me era familiar no Brasil, diretamente relacionado com as representações sobre aqueles rotulados como favelados, já que sobre esses indivíduos também uma opera uma forte relação de representações que reforçam estigmas orientados pelas moralidades dominantes.

No campo do judiciário tais discursos difundem fazeres judiciais que impactam, por exemplo, no que se refere à decisão sobre a aplicação de medidas cautelares impostas para estrangeiros. Embora a Espanha tenha um índice de prisão preventiva diminuto mesma em comparação no cenário europeu - totalizando pouco mais de $15 \%$ da população carcerária, segundo dados do Conselho da Europa de $2016^{2}$ - percebi no campo a partir das declarações de meus interlocutores, tendência à decretação de prisões preventivas em situações de flagrante nos casos envolvendo imigrantes. O principal fundamento mobilizado por meus interlocutores para aplicação da medida é o receio de fuga.

\footnotetext{
- Eles têm outra nacionalidade, isso é uma vantagem. Podem sair do país por terra, pegar um voo saindo de outro país da União Europeia e até voltar para os seus países de transporte terrestre. $O$ continente tem disso. Não temos como controlar as fronteiras, não existe um sistema integrado com todos os países da União. Já pegou um carro pra ir daqui à Portugal ou até a França? Você nem sabe quando chegou ou quando saiu da Espanha. Sai do controle, é impossível. Com disposição atravessa você tudo até de carro, chega na Rússia, na Ucrânia...

- Mas uma medida de apreensão do passaporte não resolveria esse problema?

- Pra quem é parte da União Europeia não, porque sai e entra só com identidade. Mesmo assim... a pessoa já entra no país por meios duvidosos. O tanto de gente ilegal que eu vejo aqui todo dia. Sumir é fácil, até mais fácil do que entrar. As autoridades de imigração dão até adeus.

(Notas do caderno de campo - Tradução Livre)
}

Meu principal interlocutor também não apresentava muita resistência em aplicar medida de prisão preventiva para imigrantes, mas só o fazia em casos de tráfico de drogas com notórias quantidades e crimes praticados com violência. Ele também compartilhava o argumento da maior probabilidade de fuga, fundamentando a decisão na falta de arraigo dos acusados.

2 Fonte: Prision Studies. Disponível em: https://www.prisonstudies.org/country/spain. Acesso: 16/05/2020. 
A maioria não tem vínculos fortes no país. Vem porque algum companheiro veio, disse que era tranquilo. Aí chega aqui vê que a vida não é fácil. Acabam cometendo um crime. Às vezes o crime é até pra poder se manter aqui. Vê a situação dos manteros (vendedores ambulantes). Foi criminalizada essa atividade, mas vai em Madrid ou Barcelona. É o que mais tem na rua e é crime. Mas precisam viver, não encontram lugar no mercado formal porque não têm a documentação pra trabalhar. Eu entendo... Todo mundo quer uma oportunidade. Mas aí se comete um crime violento, comete um estelionato com várias pessoas idosas... É pego transportando quilos $e$ mais quilos de drogas. Não posso ignorar. Então eu avalio se tem família, há quantos anos vive aqui, se tem filhos. Se ele não tem vínculos, se não tem raízes, ele é um provável caso de fuga porque não tem nada a perder. Daí eu decreto a prisão preventiva mesmo, mas sempre considerando essas variáveis do arraigo.

(Notas do caderno de campo - Tradução Livre)

Ao acompanhar o julgamento de casos de tráfico de drogas em Málaga pude compreender sobre as especificidades daquela sociedade ao lidar com bens individuais fundamentais. Ora, sempre tive claro que julgar, em qualquer parte do mundo, é um exercício moral, que envolve, portanto, a assimilação de moralidades e representações previamente construídas sobre contextos e situações fáticas específicas (BECKER, 2008; GOFFMAN, 1975). Todavia, as práticas dos atores judiciais na Espanha, sobretudo juízes e fiscais (acusadores), permitiram refletir sobre o exercício dessas moralidades ao pensar sobre o cenário que observei no Rio de Janeiro.

É evidente que na Espanha, assim como no Brasil, existe um processo de sujeição criminal que opera naquilo que se refere aos mecanismos de criminação e incriminação (MISSE, 2010) direcionado a perfis específicos de indivíduos, no controle de classes perigosas (BAUMAN, 2017). Se no Rio de Janeiro o banco dos réus é iminentemente ocupado por jovens, não brancos, oriundos de segmentos precários (PIRES, 2017) da sociedade brasileira, na Espanha a seletividade recai sobre ciganos e imigrantes, iminentemente marroquinos, sulamericanos e cidadãos da África subsaariana. No entanto, identifico que a condução dos julgamentos de casos envolvendo este perfil de pessoas em Málaga, difere significativamente do contexto que previamente observei no Rio de Janeiro, conforme demonstrarei no tópico a seguir. 


\section{O RITUAL DO JUICIO ORAL E A CENTRALIDADE DO RÉU}

O Juicio aconteceu durante três dias. O caso que envolvia tráfico de drogas e proxenetismo em uma casa de prostituição da cidade me explicou sobre a centralidade da oralidade no ritual. Quinze pessoas foram apresentadas como rés, denunciadas por manter em funcionamento o comércio destinado à exploração sexual e à venda de drogas em seu interior. Uma investigação maior que envolvia tráfico de seres humanos durou quase dez anos e levou à essa casa de prostituição, dentre muitas outras no país, como destino das pessoas. Ao longo das audiências vítimas e testemunhas foram ouvidas sobre as condições de trabalho no que se refere aos horários e jornadas excessivas, assim como exigência de vestuário específico fornecido pelo próprio estabelecimento mediante o pagamento de altas quantias.

Um dos acusados no processo era imigrante da Argélia de vinte e poucos anos de idade. As investigações levaram a ele como gerente do local, principal responsável pela venda de drogas na casa de prostituição. Nesse caso em específico, ao longo de todo o Juicio Oral foram ouvidas diversas testemunhas. A maior parte delas eram garotas de programa, profissionais do local alvo da investigação. Todas imigrante. A maioria do Leste Europeu, outras vindas da América do Sul e da África Subsaariana.

Durante duas horas as testemunhas explicaram sobre as atividades dos réus acusados, ressaltando que o argeliano não era o proprietário do local, embora tivesse trabalhado na função de gerência por alguns meses. No entanto, os testemunhos esclareceram aquilo que o réu já contara em seu depoimento: havia uma relação de hierarquia e submissão entre ele os proprietários do local. De fato, o homem fomentava a venda de drogas no estabelecimento, controlando o caixa de entrada e saída das substâncias. Ele cuidava do estoque, atualizando dados sobre quantidades e valores. Conduto, ficou demonstrado que havia uma relação de submissão entre ele e os demais acusados, que envolvia uma meta de vendas e produtividade.

Toda essa premissa era sustentada por uma relação de dependência, que envolvia além da situação administrativa de permanência no país das pessoas que ali trabalhavam, uma limitação de alimentação e saídas do local de trabalho. Uma das prostitutas relatou que era obrigada a "empurrar" cocaína para seus clientes, devendo atingir uma cota de vendas. A mesma mulher narrou que em uma ocasião ficou doente e impossibilitada de trabalhar durante 
duas semanas, como consequência disso não teve a meta atingida. Ela contou que naquele mês foi impedida de sair do local pelas duas semanas seguintes, impossibilitada de ir ao mercado e até à farmácia. Além de não receber nenhuma remuneração no mês, a comida também foi fracionada. Outra mulher contou que a violência física também era frequente quando as metas não eram atingidas as punições vinham na forma de socos, puxões de cabelo, queimaduras com cigarros, entre outros.

O juiz ao decidir sobre o caso levou em consideração a versão das prostitutas e do próprio réu para absolvê-lo. Quando conversamos sobre o assunto ele explicou que as provas mobilizadas ao longo do Juízo Oral foram fundamentais na construção da decisão, já que o depoimento e o testemunho do réu produziram provas que frustravam as conclusões iniciais das investigações. Assim, apesar de reconhecer que o crime acontecera, entendeu pela absolvição do réu, por conta das circunstâncias inevitáveis que o levaram a prática do crime, nos termos da teoria do direito penal, ele estava atuando em estado de necessidade, já que havia uma relação de subsistência na prática delituosa.

A partir dos casos apresentados, observo que na Espanha a característica da oralidade permite ao réu e à defesa a mobilização das mais variadas modalidades de provas disponíveis, possibilitando a desconstrução de premissas inicialmente postas. Chama a atenção o fato de que o réu é levado ao centro do processo no ato. Aliás, se observamos todo fluxo processual na Espanha, identifico uma predisposição de posicionar o réu como uma figura ativa no processo. É desejável conhecer a versão do réu sobre os fatos, inclusive nas fases de investigação. Tal característica parece colocar o réu e a atividade de defesa como um todo, numa posição de condução (co)participativa no processo. Obviamente essa característica não chega a ser tão delimitada quanto nos países integrantes da tradição da Common Law, já que tal qual acontece aqui a lógica adversarial permeia os atos e fases processuais. Contudo, a defesa consegue encontrar nessa dinâmica espaço e possibilidade real de produção de prova e narrativas, que podem ou não serem recepcionadas pelo julgador.

Esta prática certamente diverge consideravelmente do cenário que encontrei no campo do Rio de Janeiro, mais especificamente nas incursões no campo da Baixada Fluminense. Conforme demonstrarei nos tópicos subsequentes o fluxo processual no Brasil está organizado de modo a viabilizar e manter a presunção de culpa do réu. Desde os primeiros momentos de ingresso dos fatos no fluxo do sistema de justiça criminal, passando pelas decisões, pelas audiências de instrução de julgamento e chegando à sentença, o processo é instrumentalizado 
no sentido de ratificar a culpa de um sujeito que está pré-condenado. Assim, as etapas procedimentais não funcionam como uma oportunidade de apresentação de defesa, tal qual observei em Málaga, mas como uma nova oportunidade de o Estado ratificar um conhecimento produzido em uma etapa anterior.

\section{3. "ELA É UMA MULHER DIREITA" - REPRESENTAÇÕES SOBRE TESTEMUNHAS (A)CREDITÁ VEIS NO CONTEXTO RIO DE JANEIRO}

A oitiva dos policiais militares ratificou aquilo descrito na peça acusatória apresentada pelo Ministério Público. Os policiais declararam que estavam em policiamento de rotina em uma rua identificada por eles como área tranquila quando avistaram dois indivíduos numa moto, descendo a ladeira de uma rua que dá acesso a um morro da cidade. Esse morro, por sua vez, foi classificado como área complicada.

O primeiro policial militar contou que havia dois rapazes numa moto Honda de cor verde. Segundo ele, o motorista além de não parar quando solicitado, abriu fogo contra a polícia, o que resultou numa troca de tiros e num sujeito caído ao chão, após ser baleado na altura do ombro direito. Ainda segundo os policiais, o carona da moto, que era menor de idade, tentou fugir quando viu o colega se contorcendo em dores na calçada. Sem sucesso, ele foi capturado pelo segundo policial numa rua mais à frente. A denúncia enquadrava o réu em três crimes: associação para o tráfico de drogas, resistência à prisão e corrupção de menores. Durante seus testemunhos os policiais ainda esclareceram que não foi apreendida nenhuma droga na posse do réu e que, a arma usada por eles teria sido descartada pelo adolescente na rua onde ele foi capturado enquanto tentava fugir.

Tudo corria como de costume e o caso se encaminhava como de rotina, levando a entender que tratava-se de mais um caso semelhante (GARAU, 2021, no prelo). No entanto, a testemunha de defesa chamou a atenção da juíza. Era uma mulher de cerca de 55 anos de idade, loira, cabelo liso e pele bem clara, com pouquíssimas marcas do tempo. Os óculos escuros seguravam o cabelo fino por detrás das orelhas que exibiam uma sequência de três brincos dourados. Ela vestia uma calça preta de tecido de alfaiataria e uma blusa verde de seda manga $3 / 4$, calçava uma sandália de salto alto de cor nude e tiras grossas. No antebraço uma bolsa 
quadrada na cor vinho, identificada pela juíza como “uma Versace original”. Quando a mulher se acomodou no lugar a ela indicado, repousou as mãos sobre a mesa deixando em evidência as unhas bem-feitas e os muitos anéis de ouro que estavam distribuídos entre os dedos da mão direita. No dedo anelar da mão esquerda um anel reluzente, se destacava mais que os demais. Diamantes que "brilhavam mais do que o lanterna verde", nas palavras da juíza.

Helena se identificou como moradora da cidade desde o seu nascimento. Estava ali para testemunhar porque teria presenciado toda abordagem policial no caso dos dois homens na moto, da esquina da rua de sua casa, quando manobrava o carro para entrar na garagem. Ela contou que ainda era cedo, aproximadamente quatro da tarde e que se lembrava bem do horário porque havia levado sua mãe idosa e portadora da doença de Parkinson na fisioterapia, portanto uma rotina frequente de segunda a sexta feira. Ela explicava com as mãos a disposição das ruas onde tudo havia acontecido, numa tentativa desenhar sobre a mesa da sala de audiência um traçado de retas imaginárias que explicassem onde ela estava, onde era sua casa e de onde saíram os homens da moto e os policiais. $\mathrm{O}$ ir e vir das mãos fazia o anel brilhar.

A mulher estava na esquina da outra rua, de frente para sua garagem, quando viu a moto descendo o morro. Ela esperou que o veículo passasse para cruzar e parar na frente da garagem de sua casa, mas segurou o freio de seu carro quando viu a viatura da polícia e, ao mesmo tempo, identificou gritos e palavras de ordem para que a moto parasse. Foi então que Helena ouviu tiros, mas não teve a reação de se abaixar. Ao contrário, permaneceu parada, com as mãos no volante completamente estática. Por isso viu quando o motorista da moto foi baleado. Ele bateu no meio fio alto da calçada do bar da outra esquina e tombou, sem cair no chão completamente. A moto foi amparada pelo meio fio e a perna do rapaz ficou presa entre as rodas do veículo e a calçada.

A última coisa que Helena viu foram os policiais descerem apressados do carro e entrarem correndo na outra rua atrás do homem que estava na garupa. Suas pernas estavam trêmulas e as mãos suavam. Ela arrancou com o carro para dentro da garagem. Alguns dias depois ficou sabendo que os homens haviam sido presos e contou para os vizinhos que vira toda abordagem. Foi então que Helena descobriu que o motorista baleado era também um morador da rua. Ela disse não conhecer o rapaz pessoalmente, mas que seus pais viviam no bairro há pelo menos duas décadas e que nunca ouvira de ninguém sobre seu envolvimento com o tráfico de drogas. Helena ainda declarou que não houve troca de tiros entre os rapazes da moto e a polícia, ao contrário da versão apresentada por eles no testemunho imediatamente anterior ao 
dela. Os policiais militares teriam disparado quatro vezes em direção à moto, num horário em que, normalmente, há crianças brincando nas calçadas.

Após ouvir atentamente à testemunha, sem interrompê-la, a juíza lhe fez uma única pergunta: “com o que a senhora trabalha?”. Helena explicou que não trabalha. É dona de casa, dedicou a vida a cuidar de seus dois filhos, hoje adultos, ambos casados e, mais recentemente, de seus pais já idosos, com muitos problemas de saúde.

Quando a audiência acabou a juíza perguntou à secretária qual era o nome completo da mulher "do anel de diamantes". Após consultar o documento assinado por todos, referente aos testemunhos, ela ditou o nome de Helena para a juíza que o digitou em seu celular. Em poucos minutos a juíza localizou e vasculhou todo o perfil de Helena no facebook. Alguns instantes depois de interagir atentamente com a plataforma ela anunciou em voz alta para que a promotora também soubesse que Helena é casada com um engenheiro civil, dono de uma pequena construtora familiar da Zona Oeste do Rio de Janeiro, onde seus dois filhos, também engenheiros trabalham com o pai. "É uma mulher honesta", sentenciou.

Esse foi um dos casos que a juíza selecionou para elaborar ela mesma a sentença já que apesar dos elementos de semelhança era na verdade um dos casos excepcionais. Apesar de tratar-se de um caso de flagrante, cuja regra da procedimentalização (GARAU, 2021, no prelo) enseja na condenação automática do réu, esse caso apresentou elementos específicos que romperam tanto com a presunção de veracidade de testemunho policial, frustrando a regra da fé pública, quanto com a regra do flagrante delito. O motivo foi a prova testemunhal apresentada pela defesa.

Perguntei sobre Helena para a juíza e ela explicou que a mulher lhe chamou a atenção por seu perfil "diferenciado".

- Ela não tinha pinta de favelada, também não tinha pinta de bandida. Desde o momento que ela passou pela porta eu fiquei meio intrigada. Quem é que anda por essa cidade com um anel de diamante maior que o do lanterna verde e com uma bolsa da Versace pendurada no braço? Ou é gente direita ou é dona de boca, mas ela não tinha nenhum perfil de dona de boca.

- Como seria o perfil dona de boca?

- Ah, você sabe. Cordão de ouro grosso... Pele morena e cabelo amarelo palha esticado. O jeito de falar... Você sabe. Mas ela não. Era fina. Não diria bem-educada, nem bem instruída, mas uma mulher direita. Bem casada, acho que seria o caso dela.

- Por isso você procurou na internet? 
- Eu já sabia. Mas queria confirmar. Ela disse que não trabalha que é dona de casa, logo presumi que fosse o caso dela. Tantos anos nessa profissão a gente já consegue traçar o perfil das pessoas, sabe? Aqui na baixada é diferente. Tem gente não saiu daqui. Muitos foram pra Barra (da Tijuca), vê o defensor da vara aqui do lado. Nasceu aqui mora na Barra. Mas tem gente que cria raízes nesse lugar feio e não sai nunca mais. Por causa da história de vida, por causa da família, dos pais... É o caso dela e dos filhos dela.

(Notas do caderno de campo)

Ao refletir sobre o caso de Helena, me recordei de um outro caso de tráfico de drogas, cuja testemunha era também era uma moradora do local onde se deu o flagrante, algo bastante recorrente nos casos de tráfico de drogas. Carla tinha aproximadamente 30 anos de idade e se apresentou como uma moradora que, assim como Helena, nascera na cidade. A mulher era negra e estava um pouco acima do peso. O rabo de cavalo no alto da cabeça transparecia que o cabelo cacheado fora preso ainda molhado. Ela vestia uma saia florida de malha fria e uma regata branca. Levava transpassada pelos ombros uma bolsa tira colo de tecido marrom que passava por cima da alça do soutien nude que ela tentava esconder colocando para dentro da blusa, sem sucesso, enquanto contava sua versão sobre os fatos.

O caso tratava de uma apreensão de 20 gramas de cocaína numa comunidade da cidade. Os policiais, no testemunho que a antecedeu, disseram avistar um rapaz com uma mochila preta subindo o alto morro da favela durante um patrulhamento de rotina. Ele teria chamado a atenção dos policiais pois olhava para os lados com frequência e parecia estar assustado. Foi então que o flagrante aconteceu. Segundo os policiais o homem tentou correr e ofereceu muita resistência à prisão e por isso apresentava escoriações em várias partes do corpo, incluindo um braço quebrado. Como ele estava se debatendo muito, eles tiveram que usar da força para imobilizá-lo e assim, encontraram 20 gramas de cocaína na mochila do réu.

A versão de Carla contrariava aquilo apresentado pelos policiais militares. Ela contou que era por volta de oito da noite, mas que ainda não havia escurecido totalmente, por conta do horário de verão. Por isso, pode ver com clareza quando o réu foi preso. Ela estava na porta de sua casa e mexia no celular enquanto seus dois filhos brincavam no chão quando percebeu um "movimento estranho", já que identificou que os vizinhos da rua de baixo estavam entrando apressados para dentro de casa. Carla esclareceu que esse tipo de situação é recorrente no local já que há um Batalhão da Polícia Militar muito próximo ao morro onde vive. O "movimento estranho" não fazia alusão à simples passagem da viatura policial pelo local, senão uma atuação muito específica. Segundo a explicação da moradora, sempre que a polícia chega na favela 
dirigindo em baixíssima velocidade, de faróis apagados e fuzis já apontados para o exterior da viatura há um consenso local de que "coisa boa não vai dar". A expressão foi usada em alusão à troca de tiros, abordagens sem mandado, que incluem transeuntes e entrada forçada na residência dos moradores. "Eles já chegam com o intuito de esculachar mesmo".

Carla levou os filhos de 5 e 7 anos para dentro de casa e enquanto fechava o portão do quintal, viu que os policiais abordaram o réu de forma violenta. Eles ordenaram que o rapaz parasse. Ele respondeu que era trabalhador, que estava voltando do trabalho e que não tinha nada "para perder". Depois de revistar o homem, os policiais o agrediram com socos e pontapés, após ele afirmar de forma irônica "eu falei que não tinha nada".

Depois disso ela não viu mais nada, foi para dentro da casa, onde ficou até o dia seguinte quando soube pelos vizinhos que o rapaz havia sido preso por tráfico de drogas porque encontraram droga na mochila. Em seu testemunho ela explicou que o réu não levava consigo nenhuma mochila e que já o vira antes naquela localidade, mas que não o conhecia pessoalmente. No depoimento do réu ele explicou que não era morador do local, mas que passava por ali todos os dias na volta do trabalho, para ir até a sua casa que ficava mais ou menos 3 quadras depois do morro, na parte baixa, num local identificado como outro bairro. Carla explicou que o conhecia de vista já que às vezes o via por volta daquele mesmo horário.

Quando a defesa acabou de falar, a primeira pergunta da promotoria foi se a mulher conhecia o réu. Carla explicou que não o conhecia, que nunca havia se comunicado com ele, mas que já o vira outras vezes passando pela rua. "Ele é bonito, alto, chama a atenção". Foi nesse ponto da fala de Carla que a juíza interrompeu o testemunho, com impaciência.

- Afinal, a senhora conhecia ou não conhecia o réu?!

- Conhecia de vista. Não conhecia de ser amiga. Eu conhecia porque ele passava sempre pela porta da minha casa.

- Mas se a senhora não conhecia como pode afirmar que ele não é do tráfico?!

- Na favela todo mundo se conhece. Eu moro na comunidade desde que nasci, eu sei quem é cada um e ele não é um dos meninos.

- O que a senhora faz da vida?

- Sou dona de casa, cuido das crianças.

- Como é que a senhora sustenta seus filhos?

- Meu marido que trabalha, ele é auxiliar de pedreiro. Eu trabalhava de caixa de mercado até o mais velho nascer, aí meu marido falou que eu podia parar de trabalhar pra poder cuidar das crianças.

(Notas do caderno de campo) 
Quando todos saíram da sala após o depoimento do acusado, que confirmou a versão de Carla, a juíza comentou com o promotor em meio a muitas gargalhadas: "Tudo caozada, capaz da mulher ainda ser a dona da boca, olha o que eu tô te falando. Muita caozada!". O promotor comentou em tom de cumplicidade: "forçou, advogado particular sempre força muito".

$\mathrm{Na}$ sentença o depoimento da testemunha foi desconsiderado. $\mathrm{O}$ argumento mobilizado pela juíza foi no sentido de que a mulher poderia ter interesse na absolvição do réu e não havia provas concretas de que de fato ela estaria presente no momento da prisão em flagrante, porque não existia qualquer registro sobre isso no registro feito em sede policial.

\footnotetext{
(...)

A credibilidade das palavras dos policiais militares goza de prestígio ainda mais elevado em virtude destes terem afirmado que não conheciam o acusado, nem com este haver tido contatos anteriores, o que afasta qualquer propósito nefasto de prejudicá-lo gratuitamente, fato que foi confirmado pelo acusado em seu interrogatório. Ainda que assim não fosse, a Defesa sequer alegou e comprovou qualquer desentendimento anterior entre o acusado e os policiais militares arrolados na denúncia a demonstrar qualquer intenção destes em prejudicá-lo. Não é demais registrar que, caso os policiais militares tivessem uma índole distorcida, com a intenção de prejudicar o acusado, por certo, não imputariam a ele a posse de certa quantidade de drogas, 'perdendo-a's sem qualquer proveito.

(...)

(Trechos da sentença)
}

Ora, os casos anteriormente apresentados levam a concluir que não há ponderação sobre os fatos no exercício de julgar a partir da avaliação da prova testemunhal. O convencimento da juíza voltou-se exclusivamente para a pessoa da testemunha. $\mathrm{O}$ ato de julgar os fatos passa de antemão pelo julgamento da validade do testemunho, que por sua vez dependem das moralidades e representações da juíza com relação aqueles que estão testemunhando. Em ambos os casos, a decisão sobre a validade (ou não) do testemunho foi atrelada à situação econômicofinanceira das testemunhas, bem como sobre sua posição social. Embora não haja uma ponderação com relação aos fatos por si mesmos, o testemunho produz veracidade com relação aos fatos, figurando como elemento central da decisão nos "casos excepcionais", já que se avalia o valor do testemunho a partir de uma escala que hierarquiza e desiguala sujeitos. 


\subsection{A Construção do Crédito em uma sociedade de sujeitos precários e desiguais}

Ao analisar as pessoas que estão habilitadas para exercício do Comércio Ambulante, Lenin Pires (2010, p. 330) propõe o diálogo entre a "problemática que articula moral e direito". O princípio da igualdade material ou substancial, seleciona extratos da população como definitivamente desiguais. Fator que justifica a utilização do Direito, como um mecanismo promotor de equidade. Isso acontece através de um mecanismo de política compensatória, que atribui aos indivíduos em situação de desigualdade "benefícios" não necessários para os considerados em situação de igualdade (AMORIM; KANT DE LIMA; TEIXEIRA MENDES, 2005). A questão é que esta "promoção de igualdade" material interpreta a igualdade formal positivada em nossa Constituição Federal, informando que apesar de todos serem iguais perante a lei, o Direito deve proporcionar tratamento igualitário para os iguais e um tratamento desigual para os desiguais na proporção de suas desigualdades.

A principal conclusão é que nestas situações se proclama que o desenvolvimento humano, social e econômico desses sujeitos não é passível de gerar direitos, havendo uma suspeição prévia de que esse indivíduo irá romper qualquer espécie de contrato, por menos duradouro que seja. E que, portanto, durante o usufruto da concessão, ele não tem garantias quanto a sua integridade moral e física. Por isso mesmo o direito administrativo, por exemplo, refere que a atividade ambulante é exercida "por sua conta e risco" (idem, 2010).

O antropólogo sugeriu que essa é a mesma relação que acomete os moradores de favelas, que não tem direito a propriedade reconhecida, assim como de uma série de outros atores no país. O que sugere haver uma tecnologia voltada para a produção da precariedade como forma de governar. E, mais do que isso, de não garantir mediação aos riscos inevitáveis da vida em sociedade. Perceber a precariedade enquanto categoria relevante, buscando enquadrá-la como um termo dotado de sentidos mais abrangentes requer relativizar a aplicação de um direito desigual, quando este aponta para as diferenças da forma que elas te posicionam na hierarquia social brasileira; assim, ser precário ou ter um direito precário é como ter uma marca que dita o lugar ou os direitos que você receberá do Estado a partir do exercício da sua cidadania.

Estudos sobre o uso do espaço público brasileiro (DA MATTA, 1979; LIMA, 1997; LOBÃO, 1998; MOTA, 2005) apontam que a ideia de igualdade convive com a noção hierárquica na qual os diferentes direitos estão disponibilizados de acordo com a categoria que cada pessoa ocupa dentro dessa sociedade. Nesta dinâmica, a igualdade se manifesta numa 
distinção moral baseada em separar as pessoas que detém uma "substância moral das pessoas dignas" (CARDOSO DE OLIVEIRA, 2002). Dentro dessa estrutura, o testemunho policial possui mais valor do que o de uma moradora de uma favela local, tal como apresentado no caso em que Carla testemunhou. A testemunha de defesa, moradora de favela, mulher de um auxiliar de pedreiro não detém a substância moral das pessoas dignas para que lhe seja concedido crédito. Uma vez que o policial representa o Estado, quando contrastada a substância moral do policial com a testemunha a dele prevalece, uma vez que o próprio ordenamento jurídico lhe concede essa substância moral, manifesta na lógica particularista de que aquilo que é público, todas as presunções inerentes aos atos por ele praticados, uma vez o flagrante reduzido a termo pelo cartório, isso lhe concede o status de fé pública. Por outro lado, o testemunho policial dentro dessa escala de hierarquias tem seu crédito reduzido quando colacionado a de um indivíduo que pertencente a um estrato mais alto da pirâmide.

Nos casos de tráfico de drogas a figura do informante é uma constante apresentada pela defesa particular. A Defensoria Pública, ao contrário, costuma rechaçar essa modalidade por entender que a versão do informante possui o mesmo valor processual que o depoimento do réu, ou seja, de presunção de mentira. Ambos são recepcionados com descrédito pelo judiciário. Por isso, declarações de amigos, conhecidos, parentes e familiares acerca dos fatos em si, bem como sobre a vida presente e pregressa do réu são desconsiderados na construção de decisões sobre o processo. Mais uma vez tal perspectiva é orientada pelas moralidades envolvidas, preordenadas pela ideia de que tais informações são de natureza mentirosa e/ou distorcidas.

Louis Dumont (2000, p. 92-94) identifica no individualismo o fundamento da modernidade, que pode ter concepções distintas a considerar o referencial igualitário com que se concebe a inclusão dos indivíduos na sociedade. A primeira igualdade é a liberal que recomenda igualdade de direitos e oportunidades, compatível com a liberdade máxima de cada indivíduo na convivência com os demais. A segunda propõe a consolidação da igualdade de fato, a partir da abolição da propriedade privada, característica principal do modelo socialista. $\mathrm{O}$ autor compara essas concepções com a do sistema de castas, no qual a igualdade recorre às leis da troca mercantil e à identidade natural de interesses com o objetivo de assegurar a ordem. Para ele a igualdade perde seu atributo individual, dando lugar à substância da chamada "justiça social”, já que a sociedade socialista se aproxima das sociedades dividias em castas porque ambas se orientam em função das necessidades de todos. 
Nessa dinâmica, o antropólogo Lenin Pires (op. cit.) percebeu na legislação brasileira espaços para a desconstrução do sujeito de direito, uma vez que as iniciativas que deveriam promover a dignidade em prol da mobilidade do mercado não se consolidam. Resta em seu lugar a promoção de formas institucionais de controle mais atentatórias aos direitos civis. Assim, ele constrói uma interpretação sobre a categoria "precariedade", a partir do intercâmbio de significados dispostos no âmbito das chamadas ciências jurídicas. Para o autor, a condição de precariedade que é própria dos objetos, migram gradativamente para os sujeitos sociais, atingindo a necessária confiança prévia em seus propósitos de participarem dos esforços por viver em sociedade. Consequentemente, a adoção de regras legais para o tratamento de pessoas em realidades desiguais, representadas genericamente como "precárias", acabam atingindo-as em suas integridades e dignidades. A partir de estudos de segurança pública no espaço urbano carioca, Pires (2017) identificou que a distribuição desigual de direitos pela própria lei é marcada e reproduzida pelas instituições judiciais, atingindo o status social e jurídico dos sujeitos.

Ao refletir sobre a maneira como o direito administrativo conjuga a noção de precariedade, o autor conclui que o Estado define que certos atores sociais não são passíveis de estabelecer para com ele um contrato que, por exemplo, resulte na ocupação do espaço público. É o caso dos comerciantes ambulantes, como ele analisa. Isso só se verifica com esse mesmo Estado delimitando a concessão de uso em caráter precário e, logo, passível de rompimento unilateral de acordo com seu estrito desejo. O ponto do autor é que nestas situações se proclama que o desenvolvimento humano, social e econômico desses sujeitos não é passível de gerar direitos, havendo uma suspeição prévia de que esse ator irá romper qualquer espécie de contrato, por menos duradouro que seja.

O antropólogo sugeriu que essa é a mesma relação que acomete os moradores de favelas, que não tem direito a propriedade reconhecida, assim como de uma série de outros atores no país. O que sugere haver uma tecnologia voltada para a produção da precariedade como forma de governar. E, mais do que isso, de não garantir mediação aos riscos inevitáveis da vida em sociedade. Perceber a precariedade enquanto categoria relevante, buscando enquadrá-la como um termo dotado de sentidos mais abrangentes requer relativizar a aplicação de um direito desigual, quando este aponta para as diferenças da forma que elas te posicionam na hierarquia social brasileira; assim, ser precário ou ter um direito precário é como ter uma marca que dita o lugar ou os direitos que você receberá do Estado a partir do exercício da sua cidadania. 
Especificamente no contexto do judiciário essa precariedade na forma de decidir produz efeitos com relação ao jurisdicionado. Tal qual relatei no tópico referente às prisões preventivas o fato de os réus residirem em área onde a efetivação e a respectiva contraprestação pelos serviços públicos essenciais não se consolidam, há uma presunção de que a liberdade provisória do réu significa que ele irá se evadir da justiça. Chama atenção o fato de que o judiciário aceita como comprovante de residência apenas documentos oficiais para comprovação de residência aqueles expedidos por concessionária de água, gás ou energia elétrica, algo inexistência em espaços sociais favelados. Assim, réus são presumidos "precários e perigosos".

Fábio Medina (2015) ao refletir sobre as relações entre empregadas domésticas e suas patroas percebe que há uma característica da precariedade no Brasil mais especifica, a qual ele classifica como "precariedade à brasileira" já que os atores em questão são oriundos dos seguimentos de baixa renda e moradores de espaços classificados como favelas, há uma frequente desconfiança permanente com relação às domésticas. Para o autor a dinâmica é resultado do tratamento desigual concedido à classe trabalhadora na sociedade brasileira.

\subsection{Descrédito e exclusão discursiva}

Na cena das Audiências de Instrução e Julgamento observo que de acordo com as estruturas de poder inerentes ao ritual testemunhar e depor, significam discursar (FOUCAULT, 2007). Por isso, o controle, seleção, organização e redistribuição da produção de discursos operam nesse processo, valendo-se daquilo denominado pelo autor como sistemas de exclusão externos e internos ao discurso: a interdição, a oposição e a vontade de verdade. O primeiro deles, revela-se na lógica de que o réu não deve produzir provas contra si mesmo, a interdição revela por si a relação entre poder e discurso, uma vez centrada na submissão do indivíduo ao silêncio. Ora, silenciar indivíduos é parte desse complexo jogo de dissimulação no qual há uma expectativa que se converte em uma regra: a de silêncio do réu. Quando o silêncio é superado, o lugar de fala do réu se alinha com a oposição, expressa por Foucault como uma relação entre razão/loucura. Percebo desta forma, uma máxima de exclusão discursiva dos réus, dentro desta estrutura que autoriza e rechaça discursos.

A figura da loucura representa uma extensão do silêncio, já que o louco é aquele cujo discurso não pode circular como o dos outros. Ora, na sociedade brasileira o réu está numa 
condição de insulto às substâncias morais das pessoas que ocupam um lugar hierarquicamente superior, sobretudo no que se refere ao Estado (DA MATTA, 1997 e CARDOSO DE OLIVEIRA, 2002). Por isso, tal qual o louco, o réu é um indesejável, que precisa ser controlado e eliminado.

Se a razão dentro do processo penal brasileiro é construída a partir do discurso da fé pública, uma vez que os fatos sobre o qual o Estado discursa estão submetidos às regras burocráticas - no sentido weberiano da dominação legal (WEBER, 1999) que concedem a todos os atos da administração pública presunção de legitimidade, já que correspondem à forma qualquer outro discurso que vá em encontro à essa razão, é recepcionado como um irracional. A partir daí o terceiro sistema de exclusão passa a operar. É que o testemunho policial, envolto pelas teias da legalidade e, portanto, da racionalidade, ganha conotação de "verdade". Essa verdade racional alcança centralidade nas referências para avaliação do que é "falso" um falso discurso. Mas é importante ter em mente, que Michel Foucault coloca "verdadeiro" e o "falso" como dois lados de uma mesma moeda, que gira de acordo com os movimentos de escolha entre os jogadores. Isso significa dizer que nem sempre o discurso policial militar será "verdadeiro". Embora o testemunho seja referência como o discurso oficial sobre os fatos nas audiências de instrução e julgamento, a depender da substância moral e do crédito atribuído aqueles que compartilham o outro lado da moeda, o discurso verdadeiro pode se converter em "falso".

No contexto brasileiro, tal dinâmica remete à uma noção que acompanha os discursos e as práticas dos operadores jurídicos, reproduzem a doutrina de João Mendes de Almeida Júnior (1920), quando indicava a necessária correlação entre a desigualdade social e jurídica e a inquisitorialidade dos procedimentos penais, fossem eles policiais ou judiciais. Para este autor, o Estado desempenharia o papel de mediador dos conflitos da sociedade, definindo previamente, a critério dos seus agentes, qual deveria ser seu tratamento jurídico ou judiciário, conforme fossem conflitos entre iguais ou entre desiguais, considerando-se seu respectivo status social e jurídico.

Na sensibilidade jurídica brasileira os direitos da cidadania estão associados a bens raros, na medida em que são aqueles sujeitos morais dignos (CARDOSO DE OLIVEIRA, 2002; MOTA, 2005) que são detentores legítimos do reconhecimento de seus direitos de seus direitos. É por isso que a cidadania no Brasil é associada à uma dimensão regulada (SANTOS, 1987). A cidadania é associada como um recurso disponível para determinados níveis sociais, o discurso defensivo evoca a figura "trabalhador" em contraste ao "bandido". Sendo assim, os direitos da 
cidadania (MOTA, op. cit.) estão relacionados a uma concepção hierárquica na qual diferentes direitos são disponibilizados a diferentes indivíduos, a depender do lugar ocupado por cada um deles dentro da sociedade desigual. Por isso, a extensão da cidadania se dá através da regulamentação de novas profissões e/ou ocupações, ampliando os direitos associados a essas profissões, bem como pela expansão de valores inerentes ao pertencimento do indivíduo a uma comunidade. De modo que, aqueles cujas ocupações a lei desconhece, tornam-se pré-cidadãos (SANTOS, ibidem, p. 68).

Nessa dinâmica, espera-se que a aparência e o comportamento dos réus sejam compatíveis, de modo que as características visíveis relacionadas a determinado estereótipo sejam reforçadas pelas características não visíveis - trabalho, local onde moram, escolaridade, antecedente e afins. Por essa razão, os argumentos mais mobilizados pela defesa são focados em desconstruir o estigma da figura criminosa (GOFFMAN, 1975) e dar lugar a uma noção cidadania regulada (CARDOSO, 2019, p. 201).

Assim, a regra é que o testemunho policial prevalece quando em contraste com o do réu e o de outras testemunhas, já que goza do status de fé pública, inerente ao flagrante ratificado pelo cartório. Todavia, se testemunha (ou até mesmo o réu) pertencem a uma escala mais próximo do topo da pirâmide, há uma mobilização diferenciada da noção de crédito ou descrédito desse testemunho ou depoimento, já que que essa dinâmica provoca as moralidades do julgador de forma diferenciada.

Cumpre salientar que tais representações são assimiladas pelo julgador considerando os capitais simbólicos apresentados por cada um desses atores no seu papel de réu ou testemunha. Em outras palavras, se "a precariedade está hoje por toda a parte", como um efeito das lógicas neoliberais, ela não se verifica do mesmo modo.

No caso da testemunha Helena o fato de ela se apresentar naquela situação social bem vestida, portando itens pessoais de elevado valor, agregou a pessoa dela enquanto testemunha elementos simbólicos relativos ao seu capital econômico, mobilizando um processo de cisma na juíza (MOTA, 2018) com relação ao seu capital social. Da mesma forma que Carla, ao apresentar-se como uma "favelada" também o faz. Fábio Reis Mota (ibidem) colocou em cheque a tradicional observação de George Simmel (1979) no que se refere à conformação de uma sociedade de indivíduos ambientando um universo de individualismo igualitário, que permitiu a elaboração do perfil de um indivíduo blasé. A partir da problematização entre 
reconhecimento e dignidade já que a principal característica da cisma é a assimetria existente no plano das relações sociais. Isso porque, o critério de julgamento sobre o outro não se informa pela igualdade de condição, mas pelo exercício da subalternização e apagamento do outro. Assim, no âmbito das relações orientadas pela cisma, e, portanto, pela desconfiança, não há espaço para a produção de um consenso de julgamento a respeito da conduta alheia. Isso acontece porque as incertezas sempre orientam o julgamento de quem se encontra no topo da interação social.

Interessante observar que os réus e seus respectivos informantes/testemunhas, compartilham moralidades, já que mantém, geralmente, uma relação de proximidade. $\mathrm{Na}$ consolidação dessa relação impera entre os sujeitos a noção de crédito que depende da confiança na palavra. Isso foi observado por Elizabete Albernaz (2018) no Morro do Palácio, favela da região de Niterói no Rio de Janeiro e por Gabriel Borges (2020) numa favela da Zona Oeste do Rio de Janeiro. O sistema de crédito estabelecido entre os moradores locais valoriza a palavra e, portanto, aquilo que é dito. Por essa dinâmica é possível que as pessoas estabeleçam relações comerciais e de propriedade entre si. A partir da análise do cotidiano das favelas ambos identificaram que essa economia moral de proximidade e conhecimento prévio entre os sujeitos constrói crédito, conectando-se no plano cotidiano como a moralidade do cria e do raiz que se apõe à figura do vacilão. Em ambos os contextos, se funda um tipo de regime diferenciado de direitos, baseado na coloração da condição, um status que é estabelecido pelas origens do sujeito (se nascido ou criado no local) e pela sua trajetória na favela. Quanto mais próximas de um proceder de cria maior o crédito acumulado daquele indivíduo.

Ora, após a confirmação da identidade de Helena a juíza encontrou nas suas próprias moralidades elementos que atribuem crédito definitivo ao testemunho. Sobrepondo-se assim, ao testemunho policial, diferentemente do que aconteceu com no caso do testemunho de Carla. É comum que as testemunhas sejam familiares ou vizinhas do acusado e por conta dessa condição de proximidade com o réu não podem ser recebidas e ouvidas no processo na condição de testemunhas, mas somente como informantes. Isso do ponto de vista processual significa dizer que estas pessoas, tal como o réu, não estão obrigadas a falar a verdade. Tal mudança de categoria tem reflexos dentro do processo, uma vez que materialmente o testemunho deixa de ter o significado de prova e ganha a conotação de mera informação. O efeito é análogo ao relacionado à figura do réu em relação às oitivas produzidas pela acusação. Presume-se em relação ao informante uma pré-disposição a faltar com a verdade, logo, enquanto as alegações 
das testemunhas de defesa são presumidas verdadeiras, também por força de lei as alegações da defesa são presumidas falsas.

\section{CONSIDERAÇÕES FINAIS}

Apesar das proximidades de duas sensibilidades jurídicas pertencentes à tradição da Civil Law, Brasil e Espanha são orientadas por lógicas diversas no que se refere à condução dos rituais de conhecimento e julgamento de fatos classificados como crimes. Em Málaga as versões apresentadas pelos réus são levadas ao centro do processo e a fase de julgamento inaugura uma nova oportunidade de defesa. Esta característica revela que no sistema judiciário do país europeu o procedimento processual penal é central na disputa por versões com potencial de validação - ainda que dentro da lógica do contraditório. De modo que a condução do processo garante a presunção de inocência do réu, já que versões não são, desde o ponto de partida, valoradas hierarquicamente. Ao passo que, no campo do Rio de Janeiro, o procedimento não é assimilado pelos operadores como uma garantia fundamental, senão forma de reiteração/validação de verdades previamente estabelecidas pelas instituições policiais.

Desta forma, a exclusão discursiva (simbólica e expressa) dos réus e de potenciais provas defensivas perpassa por todas as fases do procedimento penal, reforçando, progressivamente, a presunção de culpa do réu, em detrimento dos preceitos de presunção de inocência que regem a ordem democrática. A principal característica do nosso sistema de justiça criminal, que mantém firmes suas raízes inquisitoriais, é atribuir presunção de veracidade a todo e qualquer ato praticado pela administração pública. Não por acaso no Rio de Janeiro o Tribunal de Justiça editou a Súmula 70, garantindo a condenação de acusados baseada exclusivamente no testemunho policial militar. Para além, há que se considerar que os documentos produzidos em sede policial (APF, inquéritos, termos circunstanciados etc.) ingressam no fluxo processual taxados pela presunção de veracidade, por força da tradição cartorial.

Nos Juicios Orales a versão do réu é levada ao centro do ritual que inaugura uma nova fase de produção de provas defensivas, retomando a noção de presunção de inocência dos réus. Assim, é oferecida ao réu uma nova oportunidade de produzir provas e disputar versões, 
amparado por uma defesa técnica. No contexto local das Varas Criminais no caso brasileiro, ao contrário, não existe a possibilidade de o réu abrir mão dessa fase de julgamento pela aceitação de um acordo. As Audiências de Instrução e Julgamento são obrigatórias para os crimes comuns, caracterizando-se assim, como uma prerrogativa do Estado em relação ao particular.

Apesar da evidente produção de significados que relaciona a figura do imigrante à prática delituosa, elevando-o ao patamar de criminoso potencial no sistema penal espanhol, essa cisão entre nós e o outro não gera automaticamente uma relação de descrédito ou descrença com relação a esses sujeitos. No caso apresentado, o fato de réu e testemunhas serem imigrantes e prostitutas, não influenciou a decisão do juiz ao considerar suas versões. Ao contrário, produziram o efeito de absolvição de um dos réus, inobstante outras provas produzidas ao longo da investigação, com o crivo do próprio Estado, apontarem para versões diversas.

O contraste leva à percepção de que na Espanha as etapas processuais inauguram novas oportunidades de o réu ter seu direito a um julgamento garantido, ainda que sob o crivo do contraditório. Mesmo na situação onde são oferecidos acordos de redução de pena, que podem ensejar na perda de mais uma oportunidade de produção de provas, a vontade do réu irá prevalecer. Novamente ele é levado ao centro do processo quando decide, com o amparo da defesa técnica, se prefere cumprir parte da pena ou se considera que seu caso pode ser levado à uma nova oportunidade de construção de narrativas para produção de provas.

No Brasil, o processo se revela como uma prerrogativa do próprio Estado de ratificar de forma hierárquica um conhecimento produzido em fase anterior, por uma instituição com uma parcela menor de poder. Afinal de contas, as instituições são dispostas numa estrutura piramidial que, não por acaso, remonta a própria estrutura da sociedade brasileira. Nessa disposição as verdades produzidas por uma instituição precisam ser ratificadas pelas outras, no sentido de ganharem mais forte conotação de verdade. Ora, aquilo narrado pelo policial militar recebe mais valor simbólico a cada fase da instrução penal ao passar pelo crivo da Polícia Civil, do Ministério Público e do magistrado. O processo orientado por essa lógica reforça e atribui maior valor simbólico, fase após fase, à versão produzida pelo próprio Estado. O processo se torna um fim em si mesmo e a única possibilidade de romper com esse ciclo que fortalece a presunção de culpa com o passar das fases e do tempo é frustrar as representações e expectativas do julgador com relação às moralidades do próprio réu. 
Ao pensar sobre os casos concretos que colocam em contraste depoimentos de réus e testemunhas de acusação e defesa identifico a prevalência de uma lógica muito específica da sociedade brasileira, que não observei no contexto espanhol - e talvez seja o maior ponto de contraste entre ambas as sensibilidades jurídicas. Na recepção de versões prevalece a daqueles sujeitos que conseguirem mobilizar mais elementos simbólicos em sua imagem real e virtual que permitam associar sua figura à reunião de bens raros, na medida em que apenas esses sujeitos morais dignos serão detentores legítimos do reconhecimento de seus direitos. Acontece que em determinadas situações sociais se proclama que o desenvolvimento humano, social e econômico de alguns sujeitos não é passível de gerar direitos, havendo uma suspeição prévia de que esse indivíduo irá romper qualquer espécie de contrato, por menos duradouro que seja.

Nos casos apresentados, a condição de descrédito está posta e previamente determinada no papel social representado e reconhecido por todos. Para além disso, as regras do jogo processual autorizam que o réu e as demais pessoas vinculadas a ele mintam, já que não estão obrigados ao dever de prestar a verdade. Enquanto, em contrapartida, com relação aos fatos construídos pelo Estado, as versões, provas e testemunhos estão corroborados pela noção de veracidade absoluta, inerente aos atos dos agentes que representam o próprio Estado. O campo mostrou, a partir das práticas do judiciário, uma ferramenta legitimadora não apenas dos discursos, mas também das práticas policiais, seja da Polícia Civil ou Militar. Ao colocar em contraste tais práticas judiciárias com aquelas que observei no contexto espanhol, chama atenção o fato de que no país europeu, ao longo da investigação e, principalmente, no Juicio Oral, é desejável conhecer a versão do réu sobre os fatos.

Essa característica parece colocar o réu e a atividade de defesa como um todo, numa posição de condução (co)participativa no processo. Obviamente essa característica não chega a ser tão delimitada quanto nos países integrantes da tradição da Common Law, já que tal qual acontece aqui, a lógica adversarial permeia os atos e fases processuais. Contudo, a defesa consegue encontrar nessa dinâmica possibilidade real de produção de prova e narrativas, que podem ou não serem recebidas pelo julgador que, por sua vez, está mais voltado para a compreensão e elucidação dos fatos com base nos elementos apresentados pelas partes do perceber ou identificar com quem são as partes envolvidas no processo. Na Baixada Fluminense observei a condução e consolidação de lógica inversa. 


\section{REFERÊNCIAS BIBLIOGRÁFICAS}

ALBERNAZ, Elisabete Ribeiro. (2018). Palácios sem reis, democracias sem cidadãos: política, cotidiano e a formação de mercados de exclusão em dois contextos do "sul-global". Tese de Doutorado. Programa de Pós-Graduação em Antropologia da Universidade Federal Fluminense.

ALMEIDA JUNIOR, João Mendes de. 1920. O processo criminal brasileiro. Vol 1. 3. ed. Rio de Janeiro: Typ. Baptista de Souza.

BAUMAN, Zygmunt. (2017). Estranhos à nossa porta. Rio de Janeiro: Zahar.

BECKER, Howard. Outsiders: estudos de sociologia do desvio. Rio de Janeiro: Jorge Zahar Ed., 2008.

BOITEUX, Luciana. (2008), "Tráfico de drogas e Constituição. Resumo do Projeto de Pesquisa apresentado ao Ministério da Justiça/PNUD”, no Projeto Pensando o Direito, Referência PRODOC BRA/08/001.

BORGES, Gabriel. "Quantos ainda vão morrer eu não sei": o regime do arbítrio, curtição vida e morte em um lugar chamado de favela. Tese (Doutorado em Sociologia e Direito) Universidade Federal Fluminense. 2018

CARDOSO DE OLIVEIRA, Luis Roberto. Direito Legal e Insulto Moral - Dilemas da Cidadania no Brasil, Quebec e EUA. Rio de Janeiro: Relume-Dumará. 2002.

CARVALHO, Jose Murilo. Cidadania no Brasil - o longo caminho. 3. ed. Rio de Janeiro: Civilização Brasileira, 2002.

DA MATTA, Roberto. A casa e a rua: espaço, cidadania, mulher e morte no Brasil. Rio de Janeiro: Guanabara, 1979.

DUMONT, Louis. $O$ individualismo. Uma perspectiva antropológica da ideologia moderna. Rio de Janeiro: Rocco. 2000.

EILBAUM, Lucia. Entre campos e academias: uma perspectiva comparada entre Brasil e Argentina. Antropolítica, v. 32, p. 195-204, 2012.

FOUCAULT, Michel. Ordem do Discurso - Aula inaugural no College de France. Pronunciada em 2 de dezembro de 1970. São Paulo. Ed. Loyola: 2007.

GARAU, Marilha Gabriela. Os modelões e a mera formalidade: produção de decisões e sentenças em uma Vara Criminal da Baixada Fluminense do Rio de Janeiro. Antropolítica. 2021. No prelo.

GOFFMAN, E. (1975). Estigma: notas sobre a manipulação da identidade deteriorada. Márcia Bandeira de Mello Leite Nunes (Trad.). Rio de Janeiro: LTC.

LIMA, Roberto Kant de. Polícia e exclusão na cultura judiciária. In: Tempo Social. Revista de Sociologia da Universidade de São Paulo, vol. 1, n. 9, mai. 1997, p. 169-183. 
. 2008. Ensaios de Antropologia e de Direito: acesso à justiça e processos institucionais de administração de conflitos e produção da verdade jurídica em uma perspectiva comparada. Rio de Janeiro: Lumen Juris. Coleção Conflitos, Direitos e Culturas.

LOBÃO, Ronaldo J.S. Servidor Público: a serviço do Estado ou a serviço do público? Monografia de conclusão do curso de Ciências Sociais da Universidade Federal Fluminense. Mimeo. 1998.

MEDINA, Fabio. Quase da família: o trabalho doméstico remunerado e as Varas do Trabalho de Niterói. 2015. Dissertação (Mestrado em Direito Constitucional) - Universidade Federal Fluminense.

MISSE, Michel. 2010. O Inquérito Policial no Brasil. Uma pesquisa empírica. Rio de Janeiro: Editora Booklink/Fenapef/Necvu.

MOTA, Fábio Reis. O Estado contra o Estado: Direito, Poder e Conflitos no Processo de Produção de Identidade "Quilombola" da Marambaia. In: KANT DE LIMA, Roberto (org.) Antropologia e Direitos Humanos. Niterói: Eduff, 2005.

Do indivíduo blasé aos sujeitos cismados: reflexões antropológicas sobre as políticas de reconhecimento na contemporaneidade. 2018. Revista Antropolítica, n. 44, Niterói, p.124-148.

PIRES, Lenin. 2010. Arreglar não é Pedir Arrego. Uma etnografia de processos de administração institucional de conflitos no âmbito da venda ambulante em Buenos Aires e Rio de Janeiro. Tese de Doutorado em Antropologia, Niterói, PPGA-UFF.

Precários e Perigosos possíveis relações entre formalidade e informalidade em processos de administração de conflitos no Rio de Janeiro. In: Disputas em torno do espaço urbano, Processos de [re]produção/construção e apropriação da cidade. John Gladhill, Maria Gabriela Hita e Mariano Perelman (orgs.). Salvador: EdUFBA, 2017. P. 335 352.

SEMER, Marcelo. (2019). Sentenciando Tráfico: o papel dos juízes no grande encarceramento. São Paulo, Tirant Brasil.

SIMMEL, Georg. A metrópole e a vida mental. In: Velho, Otávio Guilherme. (Org.). $O$ fenômeno urbano. Rio de Janeiro: Zahar editores, 1979.

SANTOS, Wanderley G. dos. Cidadania e justiça: a política social na ordem brasileira. 2. ed. São Paulo: Paulus, 1987.

WEBER, Max. Economia e sociedade: fundamentos da sociologia compreensiva. v. 1. Brasília: UnB, p. 209-227, 1999. 